\title{
ONLINE SHOPPING ORIENTATION AND PURCHASE BEHAVIOR FOR HIGH-TOUCH PRODUCTS
}

\author{
Nai-Hua Chen \\ Chienkuo Technology University \\ No.1,Chiehshou North Road, Changhua City 500, Taiwan \\ nhc@cc.ctu.edu.tw \\ Ya-Wen Hung \\ Chienkuo Technology University \\ No.1,Chiehshou North Road, Changhua City 500, Taiwan \\ amara-h@ctu.edu.tw
}

\begin{abstract}
The development of e-Commence means that many customers are familiar with this channel. While retailers have used the online channel to increase sales some items, such as socks, are less frequently purchased this way. In this study we examine the relationship between shopping orientation and online shopping behavior in the context of sock purchase. We sample 307 online shoppers. We examine whether shopping orientation affects the behavior to purchase socks online. Our analysis also considers whether the relationship between shopping orientation and purchase behavior differs according to sock types (i.e. general or specific). Recreation orientation positively, and price negatively relates to purchase behavior. Gender and sock types affect the relationship between consumer shopping orientation and purchase behavior. Males have a higher convenience orientation than females. Customers who purchase specific socks online are recreationally oriented and not concerned about price. The results indicate that when people experience more enjoyment shopping, they are more likely purchase socks online. Making online shopping interactive increases customers' recreational value and purchase behaviors.
\end{abstract}

Keywords: Shopping Orientation, Purchase Behavior, Online Shopping

\section{INTRODUCTION}

Customers' increasing interest in Internet shopping has led companies to open web-based outlets. Customers can visit and purchase from a 
web-based store at a time of their choosing. Customers find the ability to purchase products at anytime and from any place particularly appealing aspects of web-based stores. Web store environments also have certain limitations, in terms of products that can be sold, unlike traditional (physical) stores ${ }^{1}$.

Retailers typically do not sell socks online. This reflects customers' infrequent purchase of a product that they prefer to touch. Socks are very easy to purchase in Taiwan's drug stores or convenience stores. This means customers tend to avoid online purchases of this product.

The sock industry, a central part of Taiwan's industrialization in the 1970s, now faces increasing price competition. Businesses are responding by producing innovative new products and exploring other channels to engage with the market. Some companies want to develop new types of products that fit particular applications. The use of e-commerce can help retailers to target these custom products to appropriate customer segments. This study examines customers' online purchase behaviors in relation to these types of product ${ }^{2}$.

The dramatic growth in e-commerce has led researchers to focus on models that explain online purchase behaviors. The factors predict consumers' behavior towards use of this channel attracts specific attention ${ }^{2}$. By examining consumers' shopping lifestyle, it is possible to understand their attitudes towards different shopping channels ${ }^{3}$.

Shopping orientation research focuses on online behavior. Swinyard and Smith compare four online and four off-line shopper segments ${ }^{4}$. They find that online shoppers are more entertainment-oriented. Allred et al. extend this model by adding the fear of online financial risk and confusion over use of online technologies ${ }^{5}$. Allred et al. also segment online shoppers into socializers, shopping lovers, and e-value leaders. They segment off-line shoppers into fearful conservatives, shopping averters, and technology-muddlers. These orientations are important in relating customer preferences to different shopping channels ${ }^{6}$.

Customers' online shopping orientations differ by product types. Girard evaluated shopping orientation and purchase preference for various types of products ${ }^{7}$. They find that convenience and recreational orientations positively relate to online shopping preference for experience-1(clothing and perfumes), experience-2 (cell phones and television) and credence (vitamin and water purifiers) products. Nirmala and Dewi examine the relationship between shopping orientation and online purchases of fashion products on the Internet ${ }^{8}$. Results show that shopping enjoyment, price consciousness, and in-home shopping tendency all have a positive effect on consumers' 
shopping behavior for online fashion products.

Customers' shopping orientation has changed with the availability of the online channel. This research focuses exploring the factors that affect customers' online purchase behavior towards a specific or customized product. Socks are used as the example in this study. Three shopping orientations (convenience, recreation and price) are drawn from previous studies as a means examining influences on consumers' online sock purchases $^{6,9}$.

\section{CONCEPTUAL FRAMEWORK AND HYPOTHESES}

Figure 1 shows our conceptual framework. In the following sections, we introduce the theoretical background, define constructs of shopping orientation and present the hypotheses.

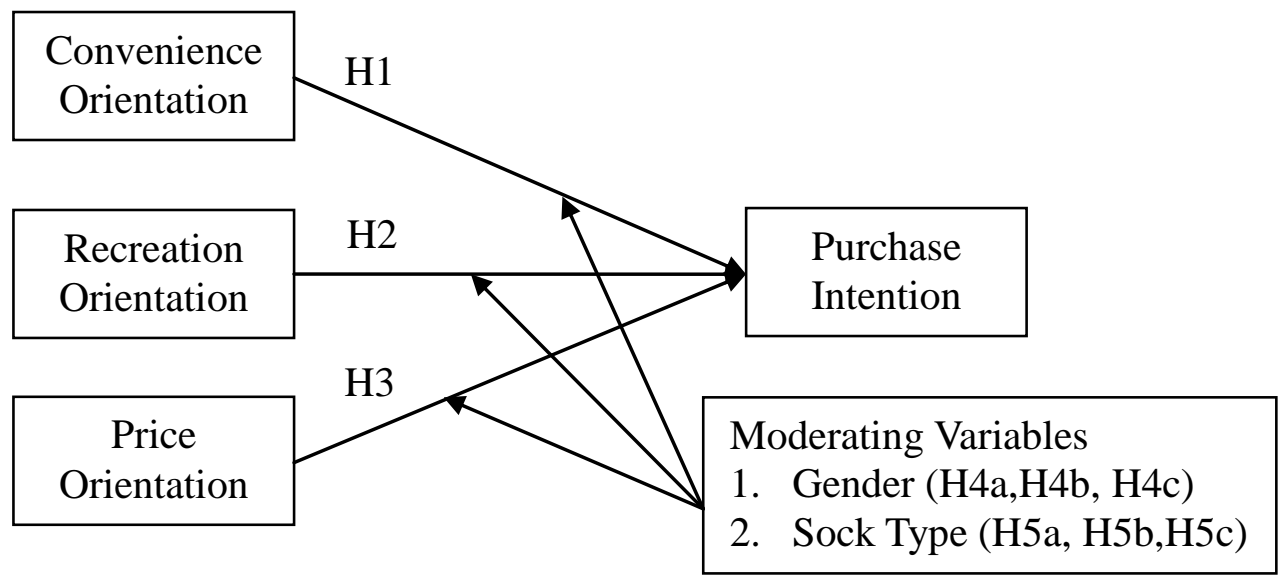

Figure 1. Research framework

\subsection{Convenience Orientation}

By allowing internet shoppers to place orders at any time of day, this channel meets customers' desire to save time and effort ${ }^{10,}{ }^{11}$. Online shopping has many advantages that include the prevention of poor customer service, making it easy to search for needs-related information and to choose the best product ${ }^{12}$. Li et al. argue that convenience-oriented customers are not concerned about touching or feeling products because of time constraints $^{2}$. Darian introduces five types of shopping needs: reducing shopping time, flexibility, spending less time in a store, saving aggravation, and impulse shopping ${ }^{13}$.

With the rapid growth of the Internet, customers have become more comfortable using e-Commence. Convenience is one important factor 
causes of shopping intention The location is irrelevant to online shoppers ${ }^{14}$. Convenience-oriented online shoppers prefer to shop at home to minimize time and effort ${ }^{7}$. Taken together, this suggests a positive relationship between convenience orientation and online shopping intentions.

H1: Convenience orientation relates positively to an intention to purchase online.

\subsection{Recreational Orientation}

Previous studies indicate that recreational shoppers shop for fun. The store décor, atmosphere, and interaction with store personnel motivate customers to shop. Since shopping is enjoyable they are not concerned about the amount of time they spend searching for product-related information or for bargains ${ }^{15}$.Retailers use product virtualization technologies to attract consumers and encourage online purchases ${ }^{16}$. They focus on improving the web aesthetics ${ }^{17}$ and making stimulus fluency ${ }^{18}$ to fulfill customers' hedonic needs. Designers are creating enjoyable online shopping experiences. We therefore propose the following hypothesis:

$\mathrm{H} 2$ : Recreational orientation relates positively with an intention to purchase online.

\subsection{Price Orientation}

Some previous studies have found that online shopping reduces the costs of information search and makes it is easier to find less expensive items $^{6,19}$. Jensen indicates that consumers are particularly sensitive to price fluctuations during economic recessions ${ }^{15}$. Girard et al. indicate that buying behavior varies by product category ${ }^{7}$. This study focuses on a product (socks) which are cheap and convenient to buy. The Internet provides rapid access to information. Customers are willing to pay more for non-regular types of socks online. We therefore propose the following hypothesis:

H3: Price orientation relates negatively to an intention to purchase online.

\subsection{Moderating Effects of Gender and Sock Types}

Brown et al. show that gender and product type might predict purchase behavior $^{3}$. To expand our understanding about how shopping orientation affects online purchase behavior, we consider gender and sock types as moderating variables (See Figure 1). Males and females differ in their shopping orientation and in their behavior towards online purchase $\mathrm{e}^{14,15,20}$. Males and females also differ in their shopping behavior ${ }^{6}$. Baker and Wakefield $^{21}$ indicate that males are task-oriented (shopping for economic and utilitarian reasons) and females are social-oriented (shopping for fun). 
Socks follow the same pattern of sensory evaluation as other clothing products $^{22}$. Sock manufactures offer different socks for different users.

We separate respondents into two groups according to whether or not they have purchased special types of socks. Special types of socks include bamboo charcoal socks, anti-fungal socks, pressure socks to reduce varicose veins regular working socks and student socks. When customers are considering to purchase special rather than basic socks, this may influence their online shopping behavior ${ }^{7,8}$. Therefore, we propose the following hypotheses:

H4a: The genders differ in the extent to which they moderate the relationship between convenience orientation and purchase behavior.

H4b: The genders differ in the extent to which they moderate the relationship between recreation orientation and purchase behavior.

$\mathrm{H} 4 \mathrm{c}$ : The genders differ in the extent to which they moderate the relationship between price orientation and purchase behavior.

H5a: Sock types differ in the way they moderate the relationship between convenience orientation and purchase behavior.

H5b: Sock types differ in the way they moderate the relationship between recreation orientation and purchase behavior.

H5c: Sock types differ in the way they moderate the relationship between price orientation and purchase behavior.

\section{METHOD}

\subsection{Data Collection}

The data was collected by self-administered questionnaire survey in Taiwan. Participants were first asked if they had ever shopped for socks online. We distributed 400 sets of questionnaires to people who had purchased socks online. After discarding invalid responses, 307 questionnaires were available for analysis (a $76.75 \%$ valid response rate). The majority of respondents (62.6\%), were women; all were over 18 years of age and more than $60 \%$ hold a undergraduate degree. Table 1 describes the sample in more detail. 
Table 1. Respondent demographics

\begin{tabular}{cccc}
\hline Variables & Classification & $\mathrm{N}$ & $\%$ \\
\hline Gender & Women & 191 & 62.6 \\
& Men & 114 & 37.4 \\
Education & & & \\
& High school and under & 95 & 31.4 \\
& University/college & 191 & 63.0 \\
Age & Graduate schools & 17 & 5.6 \\
& & & \\
& $18-20$ & 79 & 26.0 \\
& $21-25$ & 146 & 48.0 \\
& $26-30$ & 23 & 7.6 \\
& $31+$ & 56 & 18.4 \\
\hline
\end{tabular}

\subsection{Measures}

The convenience orientation used in this study was developed by Chiu et $\mathrm{al}^{23}$. The recreation orientation scale and the price orientation were adapted from Chiu et al. ${ }^{23}$ and Girard et al. ${ }^{7}$. Each item was measured on a five-point Likert-type scale from strongly disagree $(=1)$ to strongly agree $(=$ $5)$. The respondents answered the questions about shopping orientation and purchase behavior on a five-point scale. Table 2 shows that all items loaded correctly on their anticipated constructs.

\subsection{Difference across Gender and Sock Types with Shopping Orientation}

We used an independent $t$-test to examine whether gender and sock types differ significantly. Results are shown in Tables 3 and 4.In most cases, the mean values are higher for women than for men. Women compare the price of the same brand online more than men do. Customers who purchase specific types of socks have higher mean values for convenience and recreation orientation. 
Table 2. Measures and confirmatory factor analysis

\begin{tabular}{lcc}
\hline Variables & $\begin{array}{c}\text { Coefficient } \\
\text { Alpha }\end{array}$ & Estimate \\
\hline $\begin{array}{l}\text { Convenience Orientation } \\
\text { Conv1: I find it easy to obtain information when I }\end{array}$ & .850 & \\
purchase socks online. & .824 \\
$\begin{array}{l}\text { Conv2: I think it is convenient to purchase the } \\
\text { socks I want online. }\end{array}$ & .864 \\
$\begin{array}{l}\text { Conv3: I think it does not take much time to get } \\
\text { the needed information when purchasing socks }\end{array}$ & \\
$\begin{array}{l}\text { online. } \\
\text { Recreation Orientation }\end{array}$ & .742 \\
$\begin{array}{l}\text { Rec1: I feel satisfied when purchasing socks } \\
\text { online. }\end{array}$ & .768 & \\
$\begin{array}{l}\text { Rec2: I am interested in purchasing socks online. } \\
\text { Rec3: I am in a good mood when purchasing socks }\end{array}$ & & .693 \\
$\begin{array}{l}\text { online. } \\
\text { Price Orientation }\end{array}$ & .766 \\
$\begin{array}{l}\text { Price1: I compare prices when purchasing online. } \\
\text { Price2: I find bargains when purchasing online. }\end{array}$ & .724 \\
$\begin{array}{l}\text { Price3: I compare the price with the same brand } \\
\text { online. }\end{array}$ & \\
$\begin{array}{l}\text { Purchase Intention } \\
\text { Int1: I always purchase socks online when I need } \\
\text { them. }\end{array}$ & .771 \\
$\begin{array}{l}\text { Int2: I will purchase socks online in the next three } \\
\text { months. }\end{array}$ & .927 \\
Int3: I usually purchase socks via web site. & .647 \\
\hline
\end{tabular}

\section{RESULTS}

Following the two-step approach recommended by Anderson and Gerbing $^{24}$, we conducted confirmatory factor analysis (CFA) to estimate the measurement properties of multi-item constructs. 
Table 3. Gender differences

\begin{tabular}{lccccc}
\hline & \multicolumn{2}{c}{$\begin{array}{c}\text { Women } \\
(\mathrm{N}=191)\end{array}$} & \multicolumn{2}{c}{$\begin{array}{c}\text { Men } \\
(\mathrm{N}=114)\end{array}$} \\
\hline & mean & std & mean & std & $t$-value \\
\hline Convenience Orientation & & & & & \\
Conv1 & 3.36 & .86 & 3.26 & .88 & .90 \\
Conv2 & 3.30 & .98 & 3.25 & .96 & .51 \\
Conv3 & 3.35 & .89 & 3.39 & .97 & -.40 \\
Recreation Orientation & & & & & \\
Rec1 & 3.03 & .82 & 3.12 & .90 & -.91 \\
Rec2 & 3.19 & .77 & 3.12 & .89 & .74 \\
Rec3 & 3.08 & .80 & 2.97 & .93 & 1.10 \\
Price Orientation & & & & & \\
Price1 & 3.77 & .93 & 3.78 & .97 & -.13 \\
Price2 & 3.80 & .87 & 3.68 & 1.03 & .97 \\
Price3 & 3.75 & .82 & 3.56 & .94 & $1.84 *$ \\
Purchase Intention & & & & & \\
Int1 & 2.63 & 1.02 & 2.58 & 1.03 & .41 \\
Int2 & 2.64 & .98 & 2.79 & 1.11 & -1.20 \\
Int3 & 2.54 & 1.02 & 2.56 & 1.10 & -.19 \\
\hline Note $* p<.10$ & & & & &
\end{tabular}

Note: ${ }^{*} p<.10$.

\subsection{Confirmatory Factor Analysis}

We conducted CFA to test the adequacy of the measurement model in the first step of data analysis. The input matrix for the CFA was a correlation matrix, with descriptive statistics for the measures, as depicted in Table 5. Construct reliability is higher than 0.70. All acceptable average variances extracted (AVEs > .50) and composite reliability (CRs > .70) showed adequate convergent validities ${ }^{24,25}$. The construct correlations are shown in Table 6.

\subsection{Results of Structural Equation Modeling}

After we confirmed the unidimensionality of each construct, we averaged the indicators of each factor as a measure of its respective constructs in our structural equation model (SEM). We then tested our hypothesized relationships. Recreation orientation shows a positive and significant relationship with purchase intention $(\beta=.852 ; p<.01)$. Price orientation has a negative and significant relationship with purchase intention $(\beta=-.482 ; p<.01)$ (Table 7). 
Table 4. Type differences

\begin{tabular}{lccccc}
\hline & \multicolumn{2}{c}{$\begin{array}{c}\text { General } \\
(\mathrm{N}=173)\end{array}$} & \multicolumn{2}{c}{$\begin{array}{c}\text { Specific } \\
(\mathrm{N}=134)\end{array}$} \\
\hline & mean & std & mean & std & $t$-value \\
\hline Convenience Orientation & & & & & \\
Conv1 & 3.25 & .86 & 3.49 & .81 & $-2.27^{* *}$ \\
Conv2 & 3.24 & .98 & 3.40 & .93 & -1.28 \\
Conv3 & 3.41 & .94 & 3.27 & .87 & 1.15 \\
Recreation Orientation & & & & & \\
Rec1 & 3.66 & .90 & 3.74 & .31 & .31 \\
Rec2 & 3.07 & .80 & 3.03 & .98 & -.96 \\
Rec3 & 3.13 & .80 & 3.23 & .86 & $-1.84^{*}$ \\
Price Orientation & & & & & \\
Price1 & 3.67 & 1.00 & 4.02 & .73 & $-3.41^{* *}$ \\
Price2 & 3.73 & .98 & 3.83 & .84 & -.98 \\
Price3 & 3.66 & .90 & 3.74 & .80 & -.75 \\
Purchase Intention & & & & & \\
Int1 & 2.57 & 1.03 & 2.67 & 1.04 & -.77 \\
Int2 & 2.66 & 1.03 & 2.77 & 1.06 & -.86 \\
Int3 & 2.49 & 1.03 & 2.65 & 1.08 & -1.17 \\
\hline Note: $* * p<.05 ; * p .10$. & & & & & \\
& & & & &
\end{tabular}

Table 5. Confirmatory factor analysis

\begin{tabular}{lcc}
\hline & $\begin{array}{c}\text { Construct } \\
\text { Reliability (CR) }\end{array}$ & $\begin{array}{c}\text { Average variance } \\
\text { extracted(AVE) }\end{array}$ \\
\hline Purchase Intention & .899 & .749 \\
Convenience Orientation & .852 & .659 \\
Recreation Orientation & .772 & .530 \\
Price Orientation & .830 & .624 \\
\hline \multicolumn{2}{c}{ Note: Fit Statistics: $\chi^{2} / d f=1.383 ;$ GFI $=.966 ;$ AGFI $=.944 ;$ RMSEA $=.035}$.
\end{tabular}

Table 6. Constructs and correlations

\begin{tabular}{lcccccc}
\hline & Mean & $S D$ & 1 & 2 & 3 & 4 \\
\hline 1. Purchase Intention & 2.61 & .95 & $\mathbf{. 8 6 5}$ & & & \\
2. Convenience & 3.33 & .81 & .296 & $\mathbf{. 8 1 2}$ & & \\
3. Recreation & 3.09 & .69 & .636 & .596 & $\mathbf{. 7 2 8}$ & \\
4. Price & 3.74 & .79 & -.064 & .487 & .477 & $\mathbf{. 7 9 0}$ \\
\hline
\end{tabular}

Note: The square root of AVEs are shown on the diagonal. 
Table 7. SEM Results of the proposed model

Dependent Variable: Purchase Behavior

Proposed
Model Conclusion

\section{Predictors}

H1: Convenience Orientation $\rightarrow$ Purchase Intention

$.023 \quad$ Not

H2: Recreation Orientation $\rightarrow$ Purchase Intention

$.852 * * * \quad$ Supported

H3: Price Orientation $\rightarrow$ Purchase Intention

$-.482 * * * \quad$ Supported

Note: Fit statistics: $\chi^{2} / d f\left(\chi^{2}=66.369, d f=48\right)=1.383$; GFI $=.966$; AGFI $=.944$; RMSEA $=.035 ; * * * p<.01$.

\subsection{Moderating Effects}

We used subgroup SEM analysis to test the moderating effect of gender and product type on the relationships between shopping orientation and purchase intention ${ }^{26}$.A chi-square difference test was then conducted between the groups to determine whether or not their paths were significantly different.

\subsubsection{Gender}

Results show that men positively relate recreation orientation to purchase intention. Women, in contrast, negatively relate recreation to purchase intention. Both men and women show a negative and significant relationship between price orientation and purchase intention. The chi-square difference is $5.193(p<0.005)$ for the link between convenience orientation and purchase behavior; this exceeds the critical value of 3.8 for one degree of freedom. This means that $\mathrm{H} 4 \mathrm{a}$ is supported (Table 8).

Table 8. SEM results by gender

\begin{tabular}{lcccc}
\hline $\begin{array}{l}\text { Dependent Variable: Purchase } \\
\text { Behavior }\end{array}$ & $\begin{array}{c}\text { Women } \\
(\mathrm{N}=191)\end{array}$ & $\begin{array}{c}\text { Men } \\
(\mathrm{N}=114)\end{array}$ & $\Delta \chi^{2}(1)$ & Conclusion \\
\hline $\begin{array}{l}\text { Predictors } \\
\text { H4a: Convenience Orientation } \\
\rightarrow \text { Purchase Intention }\end{array}$ & -.087 & $.219 *$ & $5.193 * *$ & $\begin{array}{c}\text { Support } \\
\text { Not }\end{array}$ \\
$\begin{array}{l}\text { H4b: Recreation Orientation } \\
\rightarrow \text { Purchase Intention }\end{array}$ & $.911 * * *$ & $.757 * * *$ & 1.813 & $\begin{array}{c}\text { supported } \\
\text { Not }\end{array}$ \\
$\begin{array}{l}\text { H4c: Price Orientation } \\
\rightarrow \text { Purchase Intention }\end{array}$ & $-.520 * * *$ & $-.423 * *$ & 1.152 & \begin{tabular}{c} 
supported \\
\hline Note: Fit statistics: $\chi^{2} / d f\left(\chi^{2}=120.941, d f=96\right)=1.260 ; \mathrm{GFI}=.941 ;$ AGFI $=.903 ;$ RMSEA \\
$=.029 ; * * * p<.01, * * p<.05, * p<.10$.
\end{tabular}
\end{tabular}




\subsubsection{Sock Types}

The results show that both special and not-special sock types significantly and positively moderate the relationship between recreation orientation and purchase intention. Both sock types also significantly and negatively moderate the relationship between price orientation and purchase intention (Table 9).

Table 9. SEM results of different sock type

\begin{tabular}{|c|c|c|c|c|}
\hline $\begin{array}{l}\text { Dependent Variable: } \\
\text { Purchase Behavior }\end{array}$ & $\begin{array}{l}\text { General } \\
(\mathrm{N}=216)\end{array}$ & $\begin{array}{l}\text { Specific } \\
(\mathrm{N}=91)\end{array}$ & $\Delta \chi_{(1)}^{2}$ & Conclusion \\
\hline \multicolumn{5}{|l|}{ Predictors } \\
\hline $\begin{array}{l}\text { H5a: Convenience Orientation } \\
\rightarrow \text { Purchase Intention }\end{array}$ & -.015 & .084 & .564 & $\begin{array}{c}\text { Not } \\
\text { supported }\end{array}$ \\
\hline $\begin{array}{l}\text { H5b: Recreation Orientation } \\
\rightarrow \text { Purchase Intention }\end{array}$ & $.872 * * *$ & $.888 * * *$ & .545 & $\begin{array}{c}\text { Not } \\
\text { supported }\end{array}$ \\
\hline $\begin{array}{l}\text { H5c: Price Orientation } \\
\rightarrow \text { Purchase Intention }\end{array}$ & $-.443 * * *$ & $-.603 * * *$ & $4.559 * *$ & Supported \\
\hline
\end{tabular}

\section{CONCLUSIONS AND DISCUSSION}

Retailers face challenges because of the changes in customers' online shopping behavior. Logistics improvements make it possible for online shoppers to receive products quickly. Although it is easy to buy socks in Taiwan off-line, there is a trend towards online purchase. These online stores also offer a useful channel for retailers to sell specific or customized socks.

We examine the relationship between shopping orientation and intention to purchase socks online. We find no evidence that convenience orientation predicates customers' intention for online shopping. Recreation orientation positively, and price negatively relates to online purchase intention. This significant finding differs from previous studies that find that recreation orientation negatively, and price positively relates to purchase intention ${ }^{7}$. Shopping is not just about acquiring products. The entire shopping experience influences customers' value and loyalty. Visual technology or automotive e-service skills can enhance the shopping environment. Interactive web designs can increase the retention of online shoppers $^{27}$. When people consider buying socks online, they consider whether the product meets their requirements in addition to price. 
Gender and sock types affect consumers' shopping orientation and purchase intention. Males usually shops for products that they need. The results also prove that convenience orientation has positive effects for men. One speculation may be that men buy more specialty socks for themselves (e.g., sports socks) than women do. Women, however, may buy sock frequently for other people and so see this as a chore. Web designers can adapt business intelligent technology to direct male customer to the products that they need.

Preferences for online shopping vary by products. Some customers hesitate to purchase online products that they need to touch, smell or try for the final purchase ${ }^{2}$. This research compares the impact of product type on the relationship between shopping orientation and purchase intention. We find customers who purchase specific socks are less concerned about price. This implies that for other high-touch products, retailers should be aware of consumer needs and use combining, searching, or association algorithms to assist browsers in finding needed products.

\section{LIMITATIONS AND FURTHERE RESEARCH}

This study is limited by its focus on a single product category. The selected sample focuses on experience experienced online shoppers, who are more familiar with Internet interfaces than the general population. A more comprehensive analysis might explore the impact of familiarity with the Internet on shopping behavior. Further research could also examine variations in shopping orientation and purchase behavior. In addition, we found that recreation orientation affects Internet shopping intention. The interface quality should take into account whether using of the interface is expected a higher intention. Effects of eCommence adoption motivation such as usefulness and ease of use can be explication in the further study.

The shopping experience is important. A positive online shopping experience will enhance online shopping behavior. Shopping in a physical store might affect online shopping intention. Further research might explore the congruence of the online and offline shopping models.

\section{REFERENCES}

[1] W.R. Swinyard, and S.M. Smith, Why people (don't) shop online: A lifestyle study of the internet consumer. Psychology \& marketing, 20(7), p567-597, 2003. http://dx.doi.org/10.1002/mar.10087/.

[2] A.M. Levin, I.P. Levin, and J.A. Weller, A multi-attribute analysis of preferences for online and offline shopping: Differences across products, consumers, and shopping stages. Journal of Electronic Commerce Research, 6(4), p281-290, 2005. 
[3] M. Brown, N. Pope, and K. Voges, Buying or browsing? An exploration of shopping orientation and online purchase intention. European Journal of Marketing, 37(11/12), p1666-1684, 2003. http://dx.doi.org/10.1108/03090560310495401.

[4] P.R. Stephenson, and R.P. Willett, Analysis of consumers' retail patronage strategies. In P.R. McDonald (ed.), Marketing involvement in society and the economy (p316-322). Chicago: American Marketing Association, 1969.

[5] C.R. Allred, M. Smith, and W.R. Swinyard, E-shopping lovers and fearful conservatives: A market segmentation analysis. International Journal of Retail \& Distribution Management, 34(4/5), p308-333, 2006. http://dx.doi.org/10.1108/09590550610660251.

[6] T. Hansenand, and J.M. Jensen, Shopping orientation and online clothing purchases: The role of gender and purchase situation. European Journal of Marketing, 43(9/10), p1154-1170, 2009. http://dx.doi.org/10.1108/03090560910976410.

[7] T. Girard, P. Korgaonkar, and R. Silverblatt, Relationship of type of product, shopping orientations, and demographics with preference for shopping on the Internet. Journal of Business and Psychology, 18(1), p101-117, 2003. http://dx.doi.org/10.1023/1025087021768.

[8] N. Li, and P. Zhang, Consumer online shopping attitudes and behavior: An assessment of research. Paper presented at the 2002 Americas Conference on Information Systems, Dallas, Texas, August 9-11, 2002.

[9] K.C. Gehrt, N. Onzo, K. Fujita, and M.N. Rajan, The emergence of internet shopping in Japan: Identification of shopping orientation-defined segments. Journal of Marketing Theory and Practice, 15(2), p167-177, 2007. http://dx.doi.org/10.2753/MTP1069-6679150206.

[10] M.A. Eastlick, and R.A. Feinberg, Shopping motives for mail catalog shopping. Journal of Business Research, 45(3), p281-290, 2004. http://dx.doi.org/10.1016/S0148-2963(97)00240-3.

[11] S.M. Noble, D.A. Griffith, and M.T. Adjei, Drivers of local merchant loyalty: Understanding the influence of gender and shopping motives. Journal of Retailing, 82(3), p177-188, 2006. http://dx.doi.org/10.1016/j.jretai.2006.05.002.

[12] H. Li, C. Kuo, and M.G. Russell, The impact of perceived channel utilities, shopping orientations, and demographics on the consumer's online buying behavior. Journal of Computer-Mediated Communication, 5(2), p1-23, 1999. http://dx.doi.org/ 10.1111/j.1083-6101.1999.tb00336.x.

[13] J.C. Darian, In-Home Shopping: Are there consumer segmentation? Journal of Retailing, 63(3), p163-186, 1987. 
[14] A.J. Rohmand, and V. Swaminathan, A typology of online shoppers based on shopping motivations. Journal of Business Research, 57(7), p748-757, 2004. http://dx.doi.org/10.1016/S0148-2963(02)00351-X.

[15] J.M. Jensen, Sopping orientation and online travel shopping: The role of travel experience. International Journal of Tourism Research, 14(1), p56-70, 2012. http://dx.doi.org/10.1002/jtr.835.

[16] J. Kim, and S. Forsythe, Hedonic usage of product virtualization technologies in online apparel shopping. International Journal of Retail \& Distribution Management, 35(6), p502-514, 2007. http://dx.doi.org/10.1108/09590550710750368.

[17] Y.J. Wang, M.S. Minor, and J. Wei, Aesthetics and the online shopping environment: Understanding consumer responses. Journal of Retailing, 87(1), p46-58, 2011. http://dx.doi.org/10.1016/j.jretai.2010.09.002.

[18] H. Im, and Y. Ha, The effect of perceptual fluency and enduring involvement on situational involvement in an online apparel shopping context. Journal of Fashion Marketing and Management, 15(3), p345-361, 2011. http://dx.doi.org/10.1108/13612021111151932.

[19] R. Gulati, and J. Garino, Get the right mix of bricks \& clicks. Harvard Business Review, 78, 107-114, 2000.

[20] R.P. Nirmala, and I.J. Dewi, The effects of shopping orientations, consumer innovativeness, purchase experience, and gender on intention to shop for fashion products online. Gadjah Mada International Journal of Business, 13(1), p65-83, 2011.

[21] J. Baker, and K.L. Wakefield, How consumer shopping orientation influences perceived crowding excitement and stress at the mall. Journal of Academy Marketing Science, 40(6), p791-806, 2012. http://dx.doi.org/10.1007/s11747-011-0284-z.

[22] V.C.S. Diep, and J.C. Sweeney, Shopping trip value: Do stores and products matter? Journal of Retailing and Consumer Services, 15(5), p399-409, 2008. http://dx.doi.org/10.1016/j.jretconser.2007.10.002.

[23] K.-H. Chiu, W.-C. Wu, and T.-C. Chin, The impact of shopping orientation on online shopping adopting. Marketing Review, 3(2), p221-242, 2006. http://dx.doi.org/10.1111/j.1083-6101.1999.tb00336.x.

[24] J.C. Anderson, and D.W. Gerbing, Structural equation modeling in practice review and recommended two-step approach. Psychological Bulletin, 103(3), p411-423, 1988. http://dx.doi.org/10.1037/0033-2909.103.3.411.

[25] C.R. Fornell, and F.F. Larcker, Structural equation models with unobservable variables and measurement error. Journal of Marketing Research, 18(3), p39-51, 1981.

[26] K.A. Bollen, and R. Lennox, Conventional wisdom on measurement: Astructural equation perspective. Psychological Bulletin, 110(2), p305-314, 1991. http://dx.doi.org/10.1037/0033-2909.110.2.305. 
[27] H.H. Chang, and S.W. Chen, The impact of customer interface quality, satisfaction and switching costs on e-loyalty: Internet experience as a moderator. Computer in Human Behavior, 24(6), p2927-2944, 2008. http://dx.doi.org/10.1016/j.chb.2008.04.014. 
